\title{
Physiological concentrations of short-chain fatty acids immediately suppress colonic epithelial permeability
}

\author{
Takuya Suzuki, Shoko Yoshida and Hiroshi Hara* \\ Division of Applied Bioscience, Graduate School of Agriculture, Hokkaido University, Sapporo, Japan \\ (Received 10 July 2007 - Revised 12 November 2007 - Accepted 20 November 2007 - First published online 18 March 2008)
}

Colonic fermentation products, SCFA, have various effects on colonic functions. Here, we found that physiological concentrations of SCFA immediately promote epithelial barrier function in the large intestine. Solutions of mixed and individual SCFA were applied to the caecal walls mounted on Ussing-type chambers. Transepithelial electrical resistance (TER) increased rapidly and reached a peak $35 \%$ higher than that in the control specimen within $10 \mathrm{~min}$ post application of the SCFA mixture ( 80 acetate, 40 propionate, 20 butyrate (mmol/l)). The Lucifer yellow permeability, a paracellular transport marker, was dose-dependently reduced by the mixed SCFA, acetate and propionate solutions. Inhibition of monocarboxylate transporter-1 did not influence the increase in TER with acetate; however, lowering the pH (from 7.5 to 5.5) clearly enhanced the effect of acetate. Non-metabolizable, bromo and chloro derivatives of SCFA also increased TER. These results suggest that passive diffusion of SCFA is dominant and the metabolism of SCFA is not required for the promotive effect of SCFA on barrier function. We also observed that individual SCFA dose-dependently increased TER in T84 and Caco-2 cells, which indicates that SCFA directly stimulate epithelial cells. Depletion of membrane cholesterol and inhibitors of phosphatidylinositol-3 kinase and Gq protein attenuated the acetate-mediated promotive effect. Finally, we found that the mucosal application of the SCFA mixture dose-dependently suppressed $\left[{ }^{3} \mathrm{H}\right]$ mannitol transport from the caecal lumen to the mesenteric blood in the anaesthetized rats. We conclude that physiological concentrations of SCFA immediately enhance barrier function of the colonic epithelium through cholesterol-rich microdomain in the plasma membrane.

SCFA: Barrier function: Tight junction: Caecum: T84 cells: Caco-2 cells

The fermentation products of intestinal bacteria, SCFA, have various physiological effects on the large intestine. These organic acids promote colonic epithelial cell proliferation ${ }^{(1,2)}$, mucosal blood flow ${ }^{(3)}$ and colonic motility ${ }^{(4,5)}$. Moreover, butyrate is the principal energy source for the colonic epithelia $^{(6,7)}$ and excludes mutated mucosal cells through the induction of apoptosis ${ }^{(8,9)}$. These activities contribute to the maintenance of large intestinal function.

A number of commensal and possibly some pathogenic bacteria colonize the large intestinal lumen and produce harmful substances. To maintain beneficial relationships between the host and intestinal microbes, the barrier functions of the colonic mucosa are critical and the tight junction between the mucosal epithelial cells is the primary physical barrier in the intestines. The tight junction is composed of several transmembrane proteins, such as claudins ${ }^{(10)}$ and occludin ${ }^{(11)}$, and cytoplasmic plaque proteins, such as zonula occludens ${ }^{(12)}$.

The permeability of the tight junction is closely regulated via intracellular signalling ${ }^{(13)}$; however, there is limited information on the effects of luminal factors apart from mid-chain fatty acids, which are known to induce a rapid increase in paracellular permeability via activation of myosin light chain kinase $^{(14)}$. Non-digestible saccharides are known to enhance paracellular transport in the intestines ${ }^{(15,16)}$. It is also well known that SCFA are produced from non-digestible saccharides through intestinal bacterial fermentation. In an intestinal epithelial model consisting of cultured Caco-2 cell monolayers, SCFA, particularly butyrate, reduced monolayer permeability with increasing transepithelial electrical resistance (TER) during cell culture ${ }^{(17)}$. This effect of butyrate on TER reportedly depends on the promotion of cell differentiation, as butyrate is known as an inducer of cell differentiation ${ }^{(18,19)}$ and the significant effects on TER appeared at a considerable time, more than $24 \mathrm{~h}$, after the application of butyrate ${ }^{(17)}$.

The present study was conducted to define details of the short-term effects of SCFA on mucosal barrier function and to examine the specificity of the organic acids and involvement of intracellular signalling molecules in the SCFAmediated effect in rat isolated caecal mucosa, anaesthetized rats and cultured epithelial cell monolayers. We found that physiological concentrations of SCFA, particularly acetate, suppressed the permeability of the caecal mucosa within $10 \mathrm{~min}$. This result differs from previous observations and represents a newly identified phenomenon.

Abbreviations: CHC, 2-cyano-4-hydroxycinnamate; HBSS, Hanks' balanced salt solution; MCD, methyl- $\beta$-cyclodextrin; MCT, monocarboxylic acid transporter; Smase, sphingomyelinase; TER, transepithelial electrical resistance.

* Corresponding author: Hiroshi Hara, fax +81 11706 2504, email hara@chem.agr.hokudai.ac.jp 


\section{Materials and methods}

\section{Chemicals}

Genistein (an inhibitor of protein tyrosine kinase), LY294002 (an inhibitor of phosphatidylinositol-3 kinase), YM-254890 (an inhibitor of $\mathrm{Gq}$ protein), Calphostin $\mathrm{C}$ (a inhibitor of protein kinase C) and Y-27 536 (an inhibitor of Rho-associated protein kinase) were purchased from Calbiochem (San Diego, CA). $\left[{ }^{3} \mathrm{H}\right]$ mannitol (specific activity, $740 \mathrm{TBq} / \mathrm{mol}$ ) was purchased from American Radiolabeled Inc. (St Louis, MO, USA). All other chemicals were obtained from Wako Pure Chemical Industries, Ltd (Osaka, Japan).

\section{Animals and diets}

Male Sprague-Dawley rats (Japan SLC, Hamamatsu, Japan), weighing about $200 \mathrm{~g}$, were acclimatized with a solid unpurified diet (CE-2; Clea Japan, Tokyo, Japan) for at least $3 \mathrm{~d}$ and fasted for $1 \mathrm{~d}$ before experiments. The diet contained $50.5 \%$ carbohydrate, $25 \%$ protein, $4.7 \%$ fat, $4.0 \%$ fibre, $6.8 \%$ ash and $9 \%$ moisture.

The present study was approved by the Hokkaido University Animal Committee and animals were maintained in accordance with the Hokkaido University guidelines for the care and use of laboratory animals.

\section{Paracellular permeability in the caecal wall using Ussing chambers}

A Ussing chamber technique was used to investigate the suppressive effect of SCFA on paracellular permeability in the caecum as described previously ${ }^{(15,20)}$. Briefly, the caecum was quickly removed from rats under pentobarbital anaesthesia (sodium pentobarbital, $40 \mathrm{mg} / \mathrm{kg}$ ). Each specimen was cut open along the mesenteric border to produce a flat sheet and then rinsed with ice-cold Hanks' balanced salt solution (HBSS) $\left(117 \mathrm{NaCl}, 5.4 \mathrm{KCl}, 0.4 \mathrm{KH}_{2} \mathrm{PO}_{4}, 4.2 \mathrm{NaHCO}_{3}, 0.3\right.$ $\mathrm{Na}_{2} \mathrm{HPO}_{4}, 1.3 \mathrm{CaCl}_{2}, 0.5 \mathrm{MgCl}_{2}, 0.4 \mathrm{MgSO}_{4}, 10$ piperazine1,4-bis(2-ethanesulfonic acid) dipotassium salt, $10 \mathrm{D}$-glucose, 4 L-glutamine $(\mathrm{mmol} / \mathrm{l}), \mathrm{pH}$ 7.4). Appropriately prepared caecal tissues were mounted on Ussing chambers (Costar, Cambridge, MA, USA) that exposed a circular area of epithelium of $0.64 \mathrm{~cm}^{2}$. The serosal and mucosal sides of the specimens were bathed in $1 \mathrm{ml}$ HBSS at $\mathrm{pH} 7.4$ and 6.5, respectively, at $37^{\circ} \mathrm{C}$ to mimic physiological conditions and the medium was continuously exposed to $100 \% \quad \mathrm{O}_{2}$ gas. After a 10 min stabilization period, the mucosal medium was replaced with SCFA-containing HBSS (acetate-propionatebutyrate 80:40:20, 40:20:10 and 20:10:5 (mmol/l), $\mathrm{pH} \mathrm{6.5).}$ The composition of SCFA was based on that in the rat caecum $^{(20,21)}$. Acetate, propionate and butyrate were each added to the mucosal medium to examine the potency of individual SCFA. The effect of acetate $(40 \mathrm{mmol} / \mathrm{l})$ was examined in the mucosal medium at different $\mathrm{pH}$ values $(5 \cdot 5,6.5$ and 7.5). The $\mathrm{pH}$ in rat caecum and human faeces is reportedly between 5 and $8^{(22,23)}$. Non-metabolizable bromoacetate, chloroacetate $(80 \mathrm{mmol} / \mathrm{l})$ and bromopropionate $(40 \mathrm{mmol} / \mathrm{l})$ were added to the mucosal medium to examine whether metabolism of the SCFA is essential for their effect. The SCFA and their derivatives were substituted with $\mathrm{NaCl}$ so as not to impair the isotonicity of medium. To investigate whether monocarboxylic acid transporter (MCT)-1 is involved in the acetate effect $(80 \mathrm{mmol} / \mathrm{l})$, inhibitors of MCT-1 ${ }^{(24,25)}, 2$ cyano-4-hydroxycinnamate $(\mathrm{CHC}, 10 \mathrm{mmol} / \mathrm{l})$ and phloretin $(1 \mathrm{mmol} / \mathrm{l})$ were added to the mucosal and serosal compartments during experiments.

Paracellular permeability was evaluated by measurement of TER and unidirectional Lucifer yellow flux as described previously ${ }^{(15,16)}$. Lucifer yellow $(50 \mu \mathrm{mol} / \mathrm{l})$ was added to the mucosal medium at the beginning of incubation. After experiments, the medium was removed and fluorescence was measured using a fluorescence reader (CAF-110; JASCO International Co. Ltd, Tokyo, Japan). The mucosal:serosal flux was calculated as $\mathrm{nmol} / \mathrm{h}$ per $\mathrm{cm}^{2}$ surface area. TER was measured at various time points during the experiments using a Millicell-ERS system (Millipore, Bedford, MA, USA) as described previously ${ }^{(15,20)}$. TER was expressed as $\Omega$ per $\mathrm{cm}^{2}$ surface area or $\%$ of initial values.

Transport rates of acetate from the mucosal to serosal side were evaluated by measurement of acetate concentration transferred into the serosal medium. The concentration was measured by the previously described method using HPLC (LC-10ADpv; Shimadzu, Kyoto, Japan) equipped with two Shim-pack SCR-102H columns ( $8 \mathrm{~mm}$ internal diameter, $30 \mathrm{~cm}$ long; Shimadzu) and an electroconductibility detector (CDD-6A, Shimadzu) $^{(26)}$.

\section{Cell culture}

T84 cells (CCL-248; American Type Culture Collection, Rockville, MD, USA) and Caco-2 cells (HTB-37; American Type Culture Collection) were propagated and maintained in high-glucose ( $4.5 \mathrm{~g} / \mathrm{l}$ D-glucose) Dulbecco's modified Eagle's medium supplemented with $100 \mathrm{ml} / \mathrm{l}$ decomplemented fetal bovine serum, $44 \mathrm{mmol} / \mathrm{l}$ sodium bicarbonate, $1 \mathrm{mmol} / \mathrm{l}$ sodium pyruvate, $50000 \mathrm{U} / \mathrm{l}$ penicillin and $50 \mathrm{mg} / 1$ streptomycin and adjusted to $\mathrm{pH} 7.4$. Cells were grown on polyester membranes in Transwell inserts $(12 \mathrm{~mm}$; Costar) and experiments were conducted on days $25-27$ post seeding. T84 cells between passages 66 and 88 and Caco- 2 cells between passages $40-60$ were used for experiments.

\section{Paracellular permeability in the T84 and Caco-2 cell monolayer}

T84 and Caco- 2 cell monolayers were washed with HBSS and the basal and apical chambers of the cells were bathed in $1.5 \mathrm{ml} \mathrm{HBSS}$ at $\mathrm{pH} 7.4$ and $0.8 \mathrm{ml}$ HBSS at $\mathrm{pH} 6.5$, respectively. After a $60 \mathrm{~min}$ equilibration period, the experiments were initiated by application of SCFA-containing HBSS to the apical wells $(0-80$ acetate, $0-40$ propionate and $0-20$ butyrate $(\mathrm{mmol} / \mathrm{l}), \mathrm{pH} 6 \cdot 5)$. To examine the specificity of the suppressive effect of SCFA on paracellular permeability, three other organic acids (formate, lactate and succinate; $50 \mathrm{mmol} / \mathrm{l}$ ) were used in T84 cells. Paracellular permeability was demonstrated by measurement of TER and Lucifer yellow transport as described earlier.

\section{Treatment of cells with methyl- $\beta$-cyclodextrin and sphingomyelinase}

To examine the involvement of cholesterol-rich membrane microdomain, such as raft or caveolae, in the promotive 
effect of acetate on barrier function, methyl- $\beta$-cyclodextrin (MCD, a cholesterol-depleting agent) and sphingomyelinase (SMase) were used. Caco-2 cell monolayers were pre-treated with $\operatorname{MCD}(0,0.2$ and $0.4 \%)$ or SMase $(0,1,2 \mathrm{U} / \mathrm{ml})$ for $1 \mathrm{~h}$ prior to the experiment and incubated with or without $80 \mathrm{mmol} / \mathrm{l}$ acetate. Paracellular permeability was evaluated by measurement of TER as described earlier.

\section{Experiments with intracellular signalling inhibitors}

Caco-2 cell monolayers were pre-treated with the following six intracellular signalling inhibitors to investigate whether their activities were required for the acetate-mediated effect on barrier function: Y27632, $10 \mu \mathrm{mol} / \mathrm{l}$; genistein, $200 \mu \mathrm{mol} / \mathrm{l}$; Calphostin C, $1 \mu \mathrm{mol} / \mathrm{l}$; LY294002, $25 \mu \mathrm{mol} / \mathrm{l}$; YM-254890, $5 \mu \mathrm{mol} / \mathrm{l}$; ML-7, $30 \mu \mathrm{mol} / \mathrm{l}$. Cells were incubated with or without $80 \mathrm{mmol} / \mathrm{l}$ acetate and paracellular permeability was evaluated by measurement of TER as described earlier.

\section{Paracellular permeability in the caecum using in situ loops}

A perfusion segment of the caecum was prepared in each rat through an abdominal midline incision (about $3 \mathrm{~cm}$ ) under pentobarbital anaesthesia. Briefly, the proximal and distal ends of the caecum were tied and a small cut was made at the distal end of the caecum. The lumen was gently washed out with saline and the experiment was initiated by the injection of $3 \mathrm{ml}$ HBSS containing $\left[{ }^{3} \mathrm{H}\right]$ mannitol $(7.4 \mathrm{MBq})$ at $\mathrm{pH}$ 6.5. To examine the effect of SCFA on paracellular permeability, HBSS containing SCFA (acetate-propionate-butyrate 80:40:20 and 40:20:10 (mmol/l)) was applied. The paracellular permeability was evaluated by measurement of mannitol transport from the caecal lumen into the mesenteric blood. Blood samples were collected via the caecal vein 30 min after injection and the radioactivity of $\left[{ }^{3} \mathrm{H}\right]$ mannitol was measured by means of a liquid scintillation counting system (LSC-5100; Aloka, Tokyo, Japan) ${ }^{(16)}$. The permeability of mannitol was calculated as $\mathrm{pmol} / \mathrm{h}$ per $\mathrm{g}$ caecal tissue.

\section{Statistical analysis}

All experiments were conducted at least three times. All values are expressed as means with their standard errors of the mean. Statistical analyses was performed by a one-way ANOVA, two-way ANOVA or repeated measure two-way ANOVA followed by Duncan's multiple range test ${ }^{(27)}$ (oneway ANOVA, Tables 1, 3, 4, 5 and 7; two-way ANOVA, Tables 2 and 3 and Figs. 3 and 4; repeated measure twoway ANOVA, Figs. 1 and 2). A difference with $P<0.05$ was considered significant. These statistical analyses were performed using the general linear models procedure of the Statistical Analysis Systems program (version 6.07; SAS Institute Inc., Cary, NC, USA).

\section{Results}

TER of the caecal wall was slightly but significantly higher after a mucosal application of medium containing a low level of SCFA $(70 \mathrm{mmol} / \mathrm{l})$ compared with that after the application of a SCFA-free medium and the TER values after treatment with a high but physiological level of SCFA $(140 \mathrm{mmol} / \mathrm{l})$ was much higher than those after treatment with low levels of SCFA at all time points (Fig. 1). The TER of the caecal tissues reached a maximum 10 min after the application of 70 and $140 \mathrm{mmol} / \mathrm{l} \mathrm{SCFA}$ and maintained a high value for $60 \mathrm{~min}$. After an application of 40 or $80 \mathrm{mmol} / \mathrm{l}$ acetate and 20 or $40 \mathrm{mmol} / \mathrm{l}$ propionate, TER was dose-dependently higher than that in the absence of SCFA. Butyrate did not significantly affect caecal wall TER. We also observed that a serosal application of SCFA did not increase TER (data not shown).

Lucifer yellow transport rates, an indicator of the paracellular pathway, were dose-dependently reduced by a mucosal application of SCFA, acetate and propionate, but not by butyrate, within physiological concentrations (Table 1). The reduction in the transport rates by each application was $40-50 \%$ of the rate in the absence of SCFA.

Inhibitors of MCT-1, CHC and phloretin, which have a role in SCFA absorption in the intestinal epithelial cells, did not attenuate the increases in the TER of the caecal wall induced by the application of $80 \mathrm{mmol} / \mathrm{l}$ acetate (Table 2). The addition of CHC itself increased TER, whereas the addition of phloretin reduced TER in the absence of acetate. However, the application of $80 \mathrm{mmol} / \mathrm{l}$ acetate recovered the TER to the same level as that induced by acetate in the absence of the inhibitors.

TER and Lucifer yellow transport across the caecal wall changed in a pH-dependent manner (Table 3). Decreasing the $\mathrm{pH}$ of the mucosal medium to 5.5 amplified the enhancement of TER induced by $80 \mathrm{mmol} / \mathrm{l}$ acetate, although the change in $\mathrm{pH}$ did not have any effect on TER by itself. Paracellular transport, as indicated by Lucifer yellow, after application of acetate was higher in the $\mathrm{pH} 7.5$ medium with acetate than in the $\mathrm{pH} 6.5$ or 5.5 medium. Lucifer yellow permeability was higher in the $\mathrm{pH} 7.5$ in the absence of acetate. Acetate transport from the mucosal to serosal sides increased as the $\mathrm{pH}$ of the mucosal medium was decreased.

The caecal wall TER after an application $(80 \mathrm{mmol} / \mathrm{l})$ of acetate derivatives, bromoacetate or chloroacetate, was higher than that in the absence of SCFA (Table 4). The increased levels of TER after the application of these derivatives were similar to the level after an application of acetate. The TER after bromopropionate $(40 \mathrm{mmol} / \mathrm{l})$ treatment was also greater than that in the absence of SCFA, with the effect of bromopropionate being comparable to that of propionate.

In fully differentiated cultured T84 cell monolayers, TER increased dose- and time-dependently with increases in the physiological concentration of acetate and propionate, but not butyrate (Fig. 2). The TER of the colonic epithelium model rapidly increased after the application of 40 and $80 \mathrm{mmol} / \mathrm{l}$ acetate and reached maximum levels $30 \mathrm{~min}$ post application. The TER values in the presence of 40 and $80 \mathrm{mmol} / \mathrm{l}$ acetate and 20 and $40 \mathrm{mmol} / \mathrm{l}$ propionate were significantly higher than those in the absence of SCFA 15-120 min post application. The increases in TER by acetate and propionate were also observed in another human intestinal Caco-2 cell (Table 5). The TER values in Caco-2 cells incubated with 40 and $80 \mathrm{mmol} / \mathrm{l}$ acetate and 20 and $40 \mathrm{mmol} / \mathrm{l}$ propionate were significantly higher than each control value. The changes in TER in T84 and Caco-2 cells after the application of each SCFA were very similar to those in the rat caecal wall. 
(A)

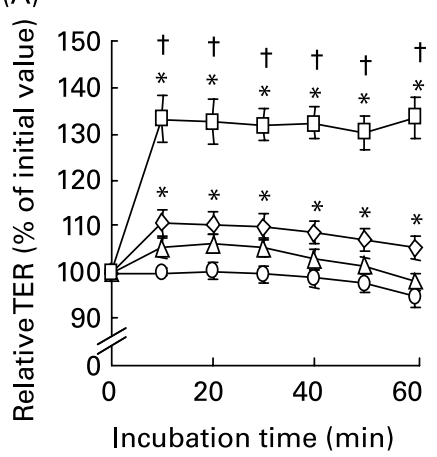

(C)

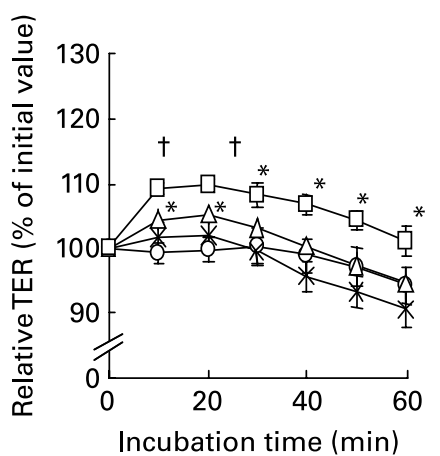

(B)

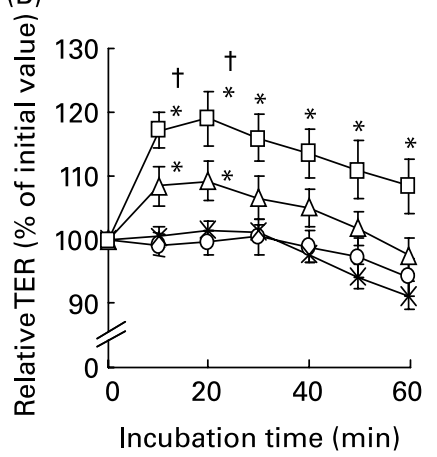

(D)

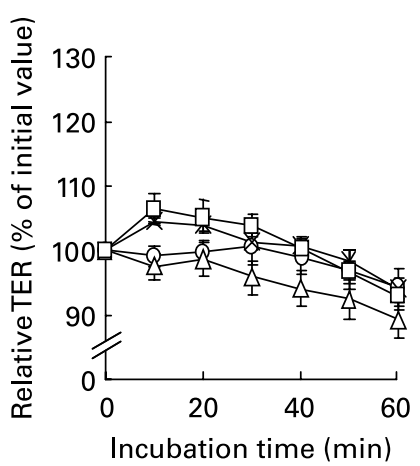

Fig. 1. Transepithelial electrical resistance (TER) in the rat caecal wall mounted on Ussing chambers incubated in the absence or presence of mixed SCFA $(O, 0 \mathrm{mmol} / \mathrm{l} ; \Delta, 35 \mathrm{mmol} / \mathrm{l} ; \diamond, 70 \mathrm{mmol} / \mathrm{l} ; \square, 140 \mathrm{mmol} / \mathrm{l})(\mathrm{A})$, acetate $(O, 0 \mathrm{mmol} / \mathrm{l} ; \times, 20 \mathrm{mmol} / \mathrm{l} ; \Delta, 40 \mathrm{mmol} / \mathrm{l} ; \square, 80 \mathrm{mmol} / \mathrm{l})(\mathrm{B}), \mathrm{propionate}(\mathrm{O}, 0 \mathrm{mmol} / \mathrm{l} ;$ $\times, 10 \mathrm{mmol} / \mathrm{l} ; \triangle, 20 \mathrm{mmol} / \mathrm{l} ; \square, 40 \mathrm{mmol} / \mathrm{l})(\mathrm{C})$ and butyrate $(O, 0 \mathrm{mmol} / \mathrm{l} ; \times, 5 \mathrm{mmol} / \mathrm{l} ; \Delta, 10 \mathrm{mmol} / \mathrm{l} ; \square, 20 \mathrm{mmol} / \mathrm{l})(\mathrm{D})$ in the mucosal chambers. Values are means with their standard errors for five rats. ${ }^{\star} P<0.05 \mathrm{v} .0 \mathrm{mmol} / \mathrm{l}$ at each time point. $\dagger P<0.05 \mathrm{v} .70 \mathrm{mmol} / \mathrm{l} \mathrm{SCFA}(\mathrm{A}), 40 \mathrm{mmol} / \mathrm{l}$ acetate $(\mathrm{B})$ and $20 \mathrm{mmol} / \mathrm{l} \mathrm{pro}-$ pionate $(C)$ at each time point. For details of animals and procedures, see Materials and methods.

The TER in T84 cell monolayers was higher $30 \mathrm{~min}$ after the application of the same concentrations $(50 \mathrm{mmol} / \mathrm{l})$ of propionate, acetate and butyrate and lactate, which increased TER in that order, compared with TER of the control group (Table 6). Formate did not change TER and succinate markedly reduced the TER of the monolayer.

Depletion of membrane cholesterol by MCD attenuated the acetate-mediated promotive effect on barrier function in a MCD dose-dependent manner (Fig. 3 (A)). The TER values in Caco- 2 cells pre-treated with 0.2 and $0.4 \%$ MCD were significantly lower than those without pre-treatment in the presence of acetate. No differences were observed in TER values between control and acetate groups in $0.4 \% \mathrm{MCD}$ treatment. The MCD treatment did not affect TER values by itself (control 1413 (SEM 18); 0.2\% MCD 1430 (SEM 73); $0.4 \%$ MCD 1406 (SEM 29), after each treatment). Digestion of sphingomyelin by SMase also impaired the acetatemediated effect on barrier function just like the MCD treatment (Fig. 3(B)). The TER value in the cells pre-treated with low-dose SMase $(1 \mathrm{U} / \mathrm{ml})$ was slightly, but not significantly, lower than that without pre-treatment in the presence of acetate. The TER values were significantly lower in the $2 \mathrm{U} / \mathrm{ml}$ SMase treatment than those in the 0 and $1 \mathrm{U} / \mathrm{ml}$ SMase treatments in the presence of acetate. There was no difference in TER values between the control and acetate groups in the $2 \mathrm{U} / \mathrm{ml}$ SMase treatment. The SMase treatment did not significantly change the TER values by itself
Table 1. Lucifer yellow transport $\left(\mathrm{pmol} / \mathrm{h}\right.$ per $\left.\mathrm{cm}^{2}\right)$ in the rat caecal wall mounted on Ussing chambers incubated in the absence or presence of mixed SCFA, acetate, propionate and butyrate in the mucosal chamberst

(Values are means with their standard errors of the mean for five rats)

\begin{tabular}{ccr}
\hline Treatment & Mean & SEM \\
\hline Mixed SCFA & & \\
$0 \mathrm{mmol} / \mathrm{l}$ & 195 & 7 \\
$35 \mathrm{mmol} / \mathrm{l}$ & 161 & 16 \\
$70 \mathrm{mmol} / \mathrm{l}$ & 160 & 17 \\
$140 \mathrm{mmol} / \mathrm{l}$ & $114^{\star}$ & 5 \\
Acetate & 122 & \\
$0 \mathrm{mmol} / \mathrm{l}$ & 113 & 14 \\
$8 \mathrm{mmol} / \mathrm{l}$ & $79^{\star}$ & 9 \\
$40 \mathrm{mmol} / \mathrm{l}$ & $76^{\star}$ & 5 \\
$80 \mathrm{mmol} / \mathrm{l}$ & & 14 \\
Propionate & 122 & 14 \\
$0 \mathrm{mmol} / \mathrm{l}$ & 101 & 15 \\
$4 \mathrm{mmol} / \mathrm{l}$ & $86^{\star}$ & 5 \\
$20 \mathrm{mmol} / \mathrm{l}$ & $68^{\star}$ & 4 \\
$40 \mathrm{mmol} / \mathrm{l}$ & & \\
Butyrate & 122 & 14 \\
$0 \mathrm{mmol} / \mathrm{l}$ & 103 & 11 \\
$2 \mathrm{mmol} / \mathrm{l}$ & 108 & 12 \\
$10 \mathrm{mmol} / \mathrm{l}$ & 90 & 7 \\
$20 \mathrm{mmol} / \mathrm{l}$ & & \\
\hline
\end{tabular}

${ }^{\star} P<0.05 \mathrm{v} .0 \mathrm{mmol} / \mathrm{l}$ of each set, Duncan's multiple range test. One-way ANOVA was performed for each set (mixed SCFA, acetate, propionate and butyrate). $\dagger$ For details of animals and procedures, see Materials and methods. 
Table 2. Transepithelial electrical resistance (\% of initial values) at 30 min in the rat caecal wall mounted on Ussing chambers incubated in the absence or presence of acetate with or without monocarboxylic acid transporter-1 inhibitors, 2-cyano-4-hydroxycinnamate and phloretin†

(Mean values with their standard errors for five rats)

\begin{tabular}{|c|c|c|c|}
\hline Treatment & Mean & & SEM \\
\hline \multicolumn{4}{|l|}{ No inhibitor } \\
\hline Control & $102^{c}$ & & 2 \\
\hline Acetate & $118^{\mathrm{b}}$ & & 3 \\
\hline \multicolumn{4}{|c|}{ 2-Cyano-4-hydroxycinnamate } \\
\hline Control & $111^{\mathrm{b}}$ & & 3 \\
\hline Acetate & $130^{\mathrm{a}}$ & & 2 \\
\hline \multicolumn{4}{|l|}{ Phloretin } \\
\hline Control & $91^{\mathrm{b}}$ & & 2 \\
\hline Acetate & $117^{\mathrm{d}}$ & & 2 \\
\hline \multicolumn{4}{|c|}{ Two-way ANOVA } \\
\hline Inhibitor (I) & & $<0.01$ & \\
\hline Acetate $(A)$ & & $<0.01$ & \\
\hline $\mathrm{I} \times \mathrm{A}$ & & $<0.01$ & \\
\hline
\end{tabular}

a,b,c,d Mean values without a common superscript letter among treatments were significantly different $(P<0.05$, Duncan's multiple range test).

$\dagger$ For details of animals and procedures, see Materials and methods.

(0 U/ml, 1628 (SEM 57); 1 U/ml, 1467 (SEM 47); 2 U/ml, 1574 (SEM 73), after each treatment).

Inhibitors of phosphatidylinositol-3 kinase and Gq protein attenuated the promotive effect of acetate on barrier function in Caco-2 cells (Fig. 4). The TER in cells with LY294002 and YM254690 was lower than that without inhibitors in the presence of acetate. The other inhibitors, Y27632, genistein, Calphostin C and ML-7, did not influence the acetate-effect. The TER value in LY294002 treatment was lower and those in YM254690 and ML-7 were higher than the control value in the absence of acetate.

Transport of $\left[{ }^{3} \mathrm{H}\right]$ mannitol, a paracellular route marker, from the caecal lumen to the mesenteric blood in anaesthetized rats after an injection of $140 \mathrm{mmol} / 1 \mathrm{SCFA}$ into the caecal lumen fell by more than $50 \%$ compared with that after the injection of a SCFA-free medium, as shown in Table 7. The suppression of paracellular transport was dose- dependent for both the SCFA mixture and acetate alone, but the changes for latter were not statistically significant.

\section{Discussion}

The present study demonstrates that higher SCFA concentrations, within the physiological range, enhance barrier function in the caecum, as indicated by increases in TER and decreases in the transport rates of a paracellular marker. The caecum is the segment of the rat alimentary tract in which the largest numbers of microbes exist. The tight junction represents a physical barrier to the intestinal epithelium ${ }^{(28,29)}$. This physical barrier is important in man and animals to prevent the permeation of toxic compounds produced by pathogenic bacteria and is also essential for them to co-exist with commensal bacteria.

We used sections of the whole caecal wall mounted on Ussing chambers to maintain the intact structure of the caecal epithelium and began experiments immediately after the removal of the tissues with confirmation of parallel changes in the paracellular transport between the whole caecal wall and the stripped caecal mucosa (unpublished results). The present study also shows rapid increases in TER in the presence of SCFA in T84 and Caco-2 cultured cell monolayers, a well-known model of the intestinal epithelium. The dose-dependent and time-dependent changes in TER induced by the apical application of acetate, propionate and butyrate were very similar to those observed in the rat caecal wall. These results reveal that the effects of SCFA in the caecum are evoked through direct action on the epithelial cells of the caecum, not on the vascular or nervous system of the caecal wall, even though SCFA are known to affect intestinal blood flow ${ }^{(3)}$ and to induce contraction of smooth muscle in the colon via the enteric nervous system $^{(5,30)}$. We also found that SCFA had a promotive effect on the caecal barrier function using anaesthetized rats. Permeation of $\left[{ }^{3} \mathrm{H}\right]$ mannitol, which is a paracellular transport marker, into the blood was markedly and dose-dependently reduced by a luminal application of SCFA at the same concentrations as those in

Table 3. Transepithelial electrical resistance, Lucifer yellow transport and acetate transport in the rat caecal wall mounted on Ussing chambers incubated in the absence or presence of acetate at various $\mathrm{pH}$ levels $(5.5,6.5$ and 7.5$)$ in the mucosal chambers ${ }^{*}$

(Mean values with their standard errors for five rats)

\begin{tabular}{|c|c|c|c|c|c|c|c|c|c|c|c|}
\hline \multirow[b]{4}{*}{$\mathrm{pH}$ in mucosal medium } & \multirow[b]{4}{*}{ Treatment } & \multicolumn{6}{|c|}{ Transepithelial electrical resistance } & & & & \\
\hline & & \multicolumn{4}{|c|}{$\Omega$ per $\mathrm{cm}^{2}$} & \multirow{2}{*}{\multicolumn{2}{|c|}{$\begin{array}{c}\begin{array}{c}\% \text { of initial } \\
\text { values }\end{array} \\
20 \mathrm{~min}\end{array}$}} & \multirow{2}{*}{\multicolumn{2}{|c|}{$\begin{array}{l}\text { Lucifer yellow } \\
\text { permeability } \\
(\mathrm{pmol} / \mathrm{h} \text { per } \\
\left.\mathrm{cm}^{2}\right)\end{array}$}} & \multirow{2}{*}{\multicolumn{2}{|c|}{$\begin{array}{l}\text { Acetate trans- } \\
\text { port }(\mathrm{nmol} / \mathrm{h} \\
\left.\text { per } \mathrm{cm}^{2}\right)\end{array}$}} \\
\hline & & \multicolumn{2}{|c|}{$0 \mathrm{~min}$} & \multicolumn{2}{|c|}{$20 \mathrm{~min}$} & & & & & & \\
\hline & & Mean & SEM & Mean & SEM & Mean & SEM & Mean & SEM & Mean & SEM \\
\hline \multirow[t]{2}{*}{$\mathrm{pH} 5.5$} & Control & 228 & 4 & 240 & 4 & $104^{c}$ & 1 & $92^{\mathrm{bc}}$ & 7 & - & - \\
\hline & Acetate & 252 & 6 & 365 & 17 & $155^{\mathrm{a}}$ & 6 & $51^{c}$ & 4 & $1 \cdot 9^{\mathrm{a}}$ & 0.2 \\
\hline \multirow[t]{2}{*}{$\mathrm{pH} 6.5$} & Control & 231 & 5 & 231 & 6 & $103^{c}$ & 3 & $103^{b}$ & 16 & - & - \\
\hline & Acetate & 252 & 10 & 298 & 17 & $121^{\mathrm{b}}$ & 5 & $77^{\mathrm{bc}}$ & 6 & $1 \cdot 6^{\mathrm{a}}$ & 0.0 \\
\hline \multirow[t]{2}{*}{$\mathrm{pH} 7.5$} & Control & 241 & 8 & 235 & 8 & $100^{c}$ & 2 & $176^{a}$ & 25 & - & - \\
\hline & Acetate & 244 & 7 & 265 & 7 & $115^{\mathrm{b}}$ & 2 & $121^{b}$ & 17 & $1 \cdot 2^{b}$ & 0.1 \\
\hline \multirow[t]{3}{*}{ One- or two-way ANOVA } & $\mathrm{pH}$ & \multicolumn{2}{|c|}{ NS } & \multicolumn{2}{|c|}{$<0.01$} & \multicolumn{2}{|c|}{$<0.01$} & \multicolumn{2}{|c|}{$<0.01$} & \multicolumn{2}{|c|}{$<0.01$} \\
\hline & Acetate & \multicolumn{2}{|c|}{ NS } & \multicolumn{2}{|c|}{$<0.01$} & \multicolumn{2}{|c|}{$<0.01$} & \multicolumn{2}{|c|}{$<0.01$} & \multicolumn{2}{|c|}{-} \\
\hline & $\mathrm{pH} \times$ Acetate & \multicolumn{2}{|c|}{ NS } & \multicolumn{2}{|c|}{$<0.01$} & \multicolumn{2}{|c|}{$<0.01$} & \multicolumn{2}{|c|}{$<0.01$} & \multicolumn{2}{|c|}{-} \\
\hline
\end{tabular}

a,b,c Mean values without a common letter among treatments were significantly different $(P<0.05$, Duncan's multiple range test).

${ }^{*}$ For details of animals and procedures, see Materials and methods. 
Table 4. Transepithelial electrical resistance (\% of initial values) at 30 min in the rat caecal wall mounted on Ussing chambers incubated in the absence or presence of derivatives of acetate and propionate in the mucosal chambers $†$

(Mean values with their standard errors for five rats)

\begin{tabular}{lcc}
\hline Treatment & Mean & SEM \\
\hline Derivatives of acetate $(80 \mathrm{mmol} / \mathrm{l})$ & & \\
$\quad$ Control & 102 & 3 \\
Acetate & $120^{\star}$ & 4 \\
Bromoacetate & $122^{\star}$ & 4 \\
$\quad$ Chloroacetate & $123^{\star}$ & 5 \\
Derivatives of propionate $(40 \mathrm{mmol} / \mathrm{l})$ & & \\
Control & 97 & 3 \\
Propionate & $113^{\star}$ & 3 \\
Bromopropionate & $111^{*}$ &
\end{tabular}

${ }^{\star} P<0.05 v$. control value of each set, Duncan's multiple range test. One-way ANOVA was performed for each set (derivatives of acetate and propionate).

† For details of animals and procedures, see Materials and methods.

the experiments using caecal tissue and cultured epithelial monolayers. The results indicate that the effects of SCFA on TER and paracellular permeation across the epithelium have physiological implications for the large intestinal barrier function.

The promotive effects of SCFA on barrier function indicated by TER appeared rapidly, just $10 \mathrm{~min}$ after mucosal application. There are a few previous reports showing that SCFA, particularly butyrate, increased the TER of Caco-2 monolayers ${ }^{(17)}$. However, that effect only emerged clearly more than $24 \mathrm{~h}$ after the addition of butyrate to the culture medium. In the present study, a physiological concentration of butyrate, which is higher than the concentration used in the previous study, did not significantly influence paracellular permeability in T84 and Caco- 2 cell monolayers or caecal tissue. Together with the much faster effects of SCFA on TER and the different specificity among each SCFA, the findings on the effects of SCFA on colonic barrier functions shown in the present study represent a distinct phenomenon and mechanism from previous observations. The long-term action of butyrate in Caco-2 monolayers shown in the previous reports is associated with the promotive effect of butyrate on cell differentiation ${ }^{(18,19)}$. On the other hand, Mariadason et al. showed that butyrate at $10 \mathrm{mmol} / 1$ increased colonic mucosal permeability and decreased $\mathrm{TER}^{(31)}$. The present findings seem to disagree with those of this previous study; however, this inconsistency is possibly caused by differences between the caecum and colon. The caecum is the predominant segment for bacterial fermentation and the production of SCFA in the rat intestines and the physiological concentration of butyrate is much higher in the caecal lumen than in the colonic lumen $^{(32)}$, which may affect the mucosal tissue response to butyrate.

We found that MCT-1 inhibitors, CHC and phloretin, did not attenuate the effect of acetate, although MCT is one of the major transporters of SCFA in intestinal cells ${ }^{(24)}$. On the other hand, lower $\mathrm{pH}$ levels in the mucosal medium clearly amplified the promotive effect of acetate on TER with concomitant increases in acetate transport. Simple diffusion of SCFA, which is another major transport pathway ${ }^{(33)}$, is accelerated at lower $\mathrm{pH}$ values, as protonated acetate more easily penetrates the cell membrane. These results suggest that the permeation of SCFA into the cell membrane, but not the uptake of SCFA by MCT-1 in the epithelial cells, is involved in the promotion of barrier function by SCFA. The reason why the media in $\mathrm{pH} 7.5$ and phloretin themselves increased
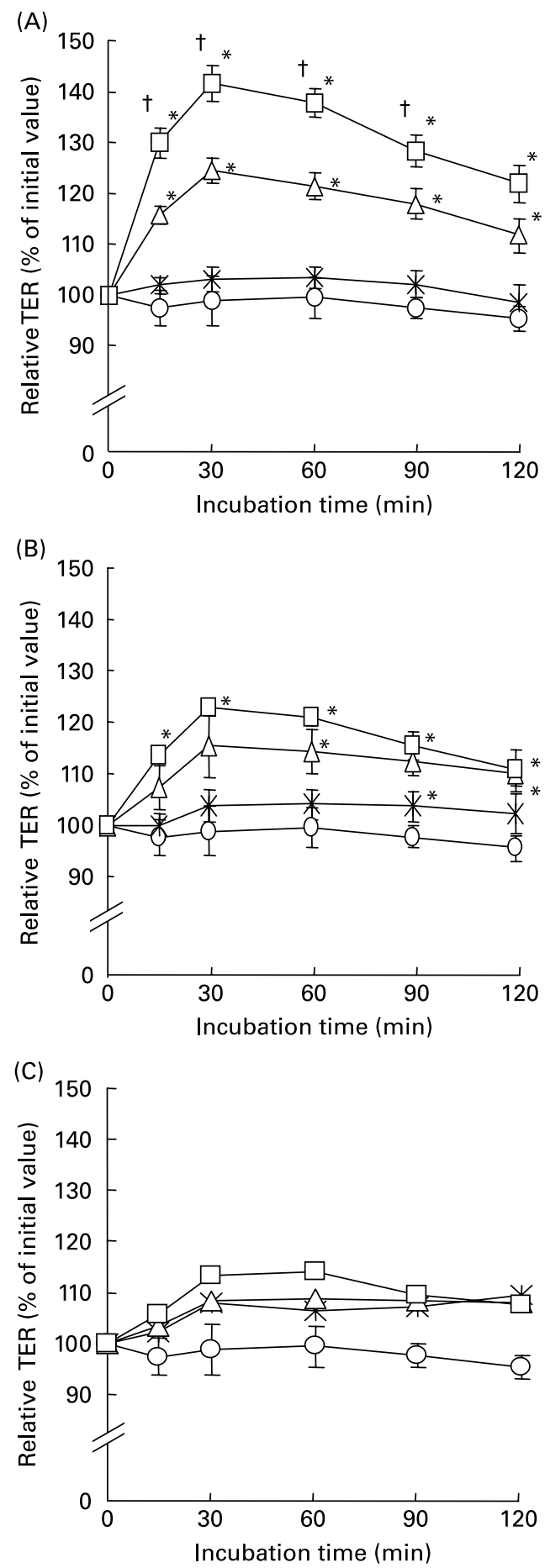

Fig. 2. Transepithelial electrical resistance (TER) in T84 cell monolayers incubated in the absence or presence of acetate $(O, 0 \mathrm{mmol} / \mathrm{l} ; \times, 8 \mathrm{mmol} / /$; $\triangle, 40 \mathrm{mmol} / \mathrm{l} ; \square, 80 \mathrm{mmol} / \mathrm{l})(\mathrm{A})$, propionate $(0,0 \mathrm{mmol} / \mathrm{l} ; \times, 4 \mathrm{mmol} / \mathrm{l} ; \Delta, 20$ $\mathrm{mmol} / \mathrm{l} ; \square, 40 \mathrm{mmol} / \mathrm{l})(\mathrm{B})$ and butyrate $(O, 0 \mathrm{mmol} / \mathrm{l} ; \times, 2 \mathrm{mmol} / \mathrm{l} ; \Delta, 10$ $\mathrm{mmol} / \mathrm{l} ; \square, 20 \mathrm{mmol} / \mathrm{l})(\mathrm{C})$ in the apical chambers. Values are means with their standard errors for five monolayers. ${ }^{\star} P<0.05 \mathrm{v} .0 \mathrm{mmol} / \mathrm{l}$ at each time point. $\dagger P<0.05$ v. $40 \mathrm{mmol} / \mathrm{l}$ acetate $(\mathrm{A})$ at each time point. For details of animals and procedures, see Materials and methods. 
Table 5. Transepithelial electrical resistance (\% of initial values) at 30 min in Caco-2 cell monolayers incubated in the absence or presence of acetate, propionate and butyrate $\dagger$

(Mean values with their standard errors for five rats)

\begin{tabular}{|c|c|c|}
\hline Treatment & Mean & SEN \\
\hline \multicolumn{3}{|l|}{ Acetate } \\
\hline $0 \mathrm{mmol} / \mathrm{l}$ & 100 & 1 \\
\hline $8 \mathrm{mmol} / \mathrm{l}$ & 112 & 1 \\
\hline $40 \mathrm{mmol} / \mathrm{l}$ & $119^{*}$ & 2 \\
\hline $80 \mathrm{mmol} / \mathrm{l}$ & $134^{*}$ & 2 \\
\hline \multicolumn{3}{|l|}{ Propionate } \\
\hline $0 \mathrm{mmol} / \mathrm{l}$ & 100 & 1 \\
\hline $4 \mathrm{mmol} / \mathrm{l}$ & 111 & 1 \\
\hline $20 \mathrm{mmol} / \mathrm{l}$ & $117^{\star}$ & 1 \\
\hline $40 \mathrm{mmol} / \mathrm{l}$ & $123^{*}$ & 1 \\
\hline \multicolumn{3}{|l|}{ Butyrate } \\
\hline $0 \mathrm{mmol} / \mathrm{l}$ & 108 & 1 \\
\hline $2 \mathrm{mmol} / \mathrm{l}$ & 113 & 1 \\
\hline $10 \mathrm{mmol} / \mathrm{l}$ & 114 & 1 \\
\hline $20 \mathrm{mmol} / \mathrm{l}$ & 115 & 1 \\
\hline
\end{tabular}

${ }^{*} P<0.05$ v. $0 \mathrm{mmol} / \mathrm{l}$ of each set, Duncan's multiple range test. One-way ANOVA was performed for each set (acetate, propionate and butyrate). † For details of animals and procedures, see Materials and methods.

paracellular permeability is unclear, although the latter is consistent with the results of previous work ${ }^{(34)}$.

We demonstrated that non-metabolizable acetate and propionate derivatives also induced the enhancement of barrier function in the caecum in a manner very similar to that of acetate and propionate themselves. This result indicates that metabolism of SCFA is not necessary to the induction of their promotive effects on TER. In our examination of the specificity of organic acids produced by caecal fermentation using T84 monolayers, three major fermentation products, acetate, propionate and butyrate, produced comparable effects on barrier function at the same concentration, which indicates that chain length of the fatty acids is not important in inducing TER enhancement. However, lactate and formate had less or no effect on TER enhancement. These results suggest that the hydrophobicity of side-chains in organic acids is involved in their effect on TER. Succinate markedly reduced the TER of the T84 monolayers. The mechanism underlying this effect is not clear, but it is possible that the chelating action

Table 6. Transepithelial electrical resistance (\% of initial values) at $30 \mathrm{~min}$ in T84 cell monolayers incubated in the absence or presence of acetate, propionate, butyrate, formate, lactate and succinate in the apical chambers*

(Mean values with their standard errors for four monolayers)

\begin{tabular}{lcc}
\hline Treatment & Mean & SEM \\
\hline Control & $111^{\mathrm{d}}$ & 3 \\
Acetate & $135^{\mathrm{b}}$ & 2 \\
Propionate & $144^{\mathrm{a}}$ & 1 \\
Butyrate & $136^{\mathrm{b}}$ & 5 \\
Formate & $115^{\mathrm{d}}$ & 1 \\
Lactate & $127^{\mathrm{c}}$ & 1 \\
Succinate & $42^{\mathrm{e}}$ & 2
\end{tabular}

$\mathrm{a}, \mathrm{b}, \mathrm{c}, \mathrm{d}, \mathrm{e}$ Mean values without a common superscript letter among treatments were significantly different $(P<0.05$, Duncan's multiple range test).

* For details of animals and procedures, see Materials and methods. of the dicarboxylic acid is responsible for the significant reduction of TER.

The function of the tight junction is regulated by many intracellular signallings ${ }^{(13)}$. Inhibitors of phosphatidylinositol-3 kinase and $\mathrm{Gq}$ protein partially attenuated the acetate-mediated promotive effect on barrier function. Recently, cell surface G-protein coupled receptors for SCFA, GPR41 and GPR43, have been defined ${ }^{(35)}$. GPR43 has been reported to express in human and rat colon enterocytes ${ }^{(36,37)}$ and couple with $\mathrm{Gq}$ and $\mathrm{Gi} / \mathrm{o}$ proteins ${ }^{(35)}$. Activation of phosphatidylinositol-3 kinase is reportedly induced via a Gq proteindependent pathway in airway smooth muscle cells ${ }^{(38)}$. Moreover, we found that depletion of membrane cholesterol by MCD and digestion of sphingomyelin by SMase abolished the acetate-mediated effect. It is known that cholesterol is a
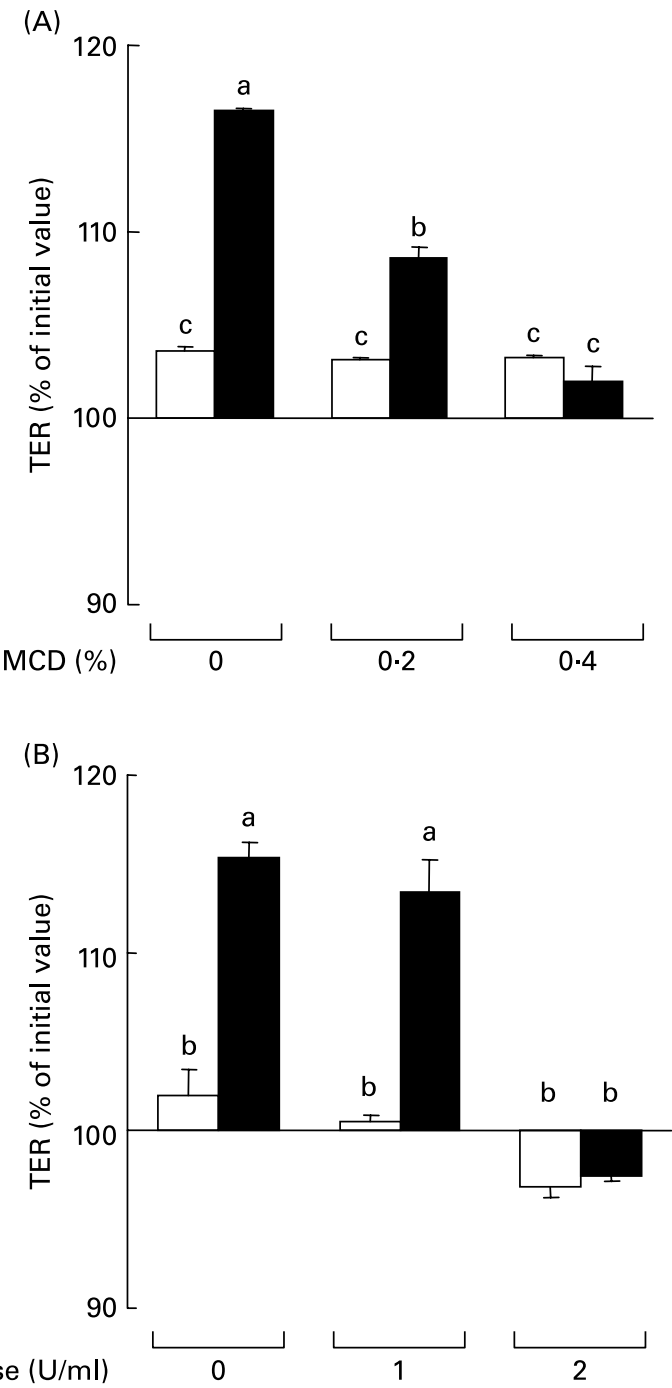

Fig. 3. Transepithelial electrical resistance (TER) at $30 \mathrm{~min}$ in Caco-2 cell monolayers incubated with or without acetate (control, $\square ; 80 \mathrm{mmol} / \mathrm{l}$ acetate, 口). Cells were pre-treated with or without methyl- $\beta$-cyclodectrin (MCD; $(A)$ ) or sphingomyelinase (SMase; $(B))$ for $1 \mathrm{~h}$ prior to incubation. Values are means with their standard errors for five monolayers. ${ }^{a, b, c}$ Mean values without a common superscript letter among treatments are significantly different $(P<0.05)$. For details of animals and procedures, see Materials and methods. 


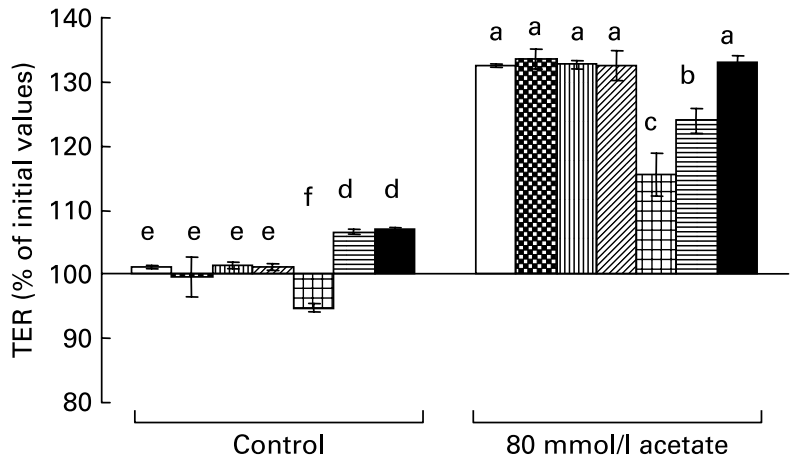

Fig. 4. Transepithelial electrical resistance (TER) at $30 \mathrm{~min}$ in Caco-2 cell monolayers incubated with or without acetate in the presence or absence of various signalling inhibitors ( $\square$, control; $\mathbf{0}$, Y27632; س, genistein; $\square$, Calphostin C; 田, LY294002; 目, YM-254690; $\mathbf{m}$, ML-7). Values are means with their standard errors for five monolayers. a,b,c,d,e,f Mean values without a common superscript letter among treatments were significantly different $(P<0.05)$. For details of animals and procedures, see Materials and methods.

key component of lipid microdomain ${ }^{(39)}$ and sphingomyelin forms tight hydrophobic interactions with cholesterol and has an important role in the formation of lipid microdomains ${ }^{(40)}$. Cholesterol-rich microdomains, such as raft or caveolae, are known to play an important role in intracellular signal transduction $^{(41)}$. It is possible that these SCFA receptors are involved in the mechanisms for the promotion of barrier function through the lipid microdomain-dependent signal transduction. However, we have to consider also the other alternative mechanism underlying the SCFA effect, because the inhibitory effect of these two signalling blockers is partial. Nusrut et al. have reported that the hyperphosphorylated forms of the tight-junction proteins occludin and $\mathrm{ZO}-1$ are associated with lipid rafts isolated from T84 cells ${ }^{(42)}$. This has led to the suggestion that lipid microdomains directly play a role in promoting tight junction assembly and integrity. Protonated SCFA, which can easily penetrate plasma membrane, may directly interact with lipid raft and promote the function of tight junctions. This may be supported by the result that lower $\mathrm{pH}$ of media enhances the acetate-mediated promotive effect.

In conclusion, physiological concentrations of acetate and propionate enhance the barrier function in the rat caecum, T84 and Caco-2 cell monolayers and the pH-dependent

Table 7. Concentration of $\left[{ }^{3} \mathrm{H}\right]$ mannitol $(\mathrm{pmol} / \mathrm{l})$ in rat serum collected from the caecal vein $30 \mathrm{~min}$ after the injection of solutions with or without mixed SCFA and acetate†

(Mean values with their standard errors for six rats)

\begin{tabular}{lll}
\hline Treatment & Mean & SEM \\
\hline Mixed SCFA & & \\
$0 \mathrm{mmol} / \mathrm{l}$ & 30.4 & 7.5 \\
$70 \mathrm{mmol} / \mathrm{l}$ & 22.3 & 3.6 \\
$140 \mathrm{mmol} / \mathrm{l}$ & $15 \cdot 0^{*}$ & 2.1 \\
Acetate & & 7.5 \\
$0 \mathrm{mmol} / \mathrm{l}$ & 30.4 & 7.0 \\
$40 \mathrm{mmol} / \mathrm{l}$ & 25.6 & 3.0 \\
$80 \mathrm{mmol} / \mathrm{l}$ & 20.2 & \\
\hline
\end{tabular}

${ }^{\star} P<0.05 v .0 \mathrm{mmol} / \mathrm{l}$ of each set, Duncan's multiple range test. One-way ANOVA was performed for each set (mixed SCFA and acetate).

† For details of animals and procedures, see Materials and methods. penetration of SCFA into epithelial cells is involved in the enhancing effect via cholesterol-rich microdomain in the plasma membrane.

\section{Acknowledgements}

We used the Radioisotope Laboratory of the Graduate School of Agriculture, Hokkaido University. There is no conflict of interest in this study.

\section{References}

1. Inagaki A \& Sakata T (2005) Dose-dependent stimulatory and inhibitory effects of luminal and serosal $n$-butyric acid on epithelial cell proliferation of pig distal colonic mucosa. J Nutr Sci Vitaminol (Tokyo) 51, 156-160.

2. Sakata T, Adachi M, Hashida M, Sato N \& Kojima T (1995) Effect of $n$-butyric acid on epithelial cell proliferation of pig colonic mucosa in short-term culture. Dtsch Tierarztl Wochenschr 102, 163-164.

3. Aaronson PI, McKinnon W \& Poston L (1996) Mechanism of butyrate-induced vasorelaxation of rat mesenteric resistance artery. Br J Pharmacol 117, 365-371.

4. Dass NB, John AK, Bassil AK, Crumbley CW, Shehee WR, Maurio FP, Moore GB, Taylor CM \& Sanger GJ (2007) The relationship between the effects of short-chain fatty acids on intestinal motility in vitro and GPR43 receptor activation. Neurogastroenterol Motil 19, 66-74.

5. McManus CM, Michel KE, Simon DM \& Washabau RJ (2002) Effect of short-chain fatty acids on contraction of smooth muscle in the canine colon. Am J Vet Res 63, 295-300.

6. Clausen MR \& Mortensen PB (1995) Kinetic studies on colonocyte metabolism of short chain fatty acids and glucose in ulcerative colitis. Gut 37, 684-689.

7. Clausen MR \& Mortensen PB (1994) Kinetic studies on the metabolism of short-chain fatty acids and glucose by isolated rat colonocytes. Gastroenterology 106, 423-432.

8. Chen J, Ghazawi FM, Bakkar W \& Li Q (2006) Valproic acid and butyrate induce apoptosis in human cancer cells through inhibition of gene expression of Akt/protein kinase B. Mol Cancer 5, 71 .

9. Kolar SS, Barhoumi R, Lupton JR \& Chapkin RS (2007) Docosahexaenoic acid and butyrate synergistically induce colonocyte apoptosis by enhancing mitochondrial $\mathrm{Ca} 2+$ accumulation. Cancer Res 67, 5561-5568.

10. Furuse M, Fujita K, Hiiragi T, Fujimoto K \& Tsukita S (1998) Claudin-1 and -2: novel integral membrane proteins localizing at tight junctions with no sequence similarity to occludin. $J$ Cell Biol 141, 1539-1550.

11. Furuse M, Hirase T, Itoh M, Nagafuchi A, Yonemura S, Tsukita S \& Tsukita S (1993) Occludin: a novel integral membrane protein localizing at tight junctions. J Cell Biol 123, 1777-1788.

12. Gonzalez-Mariscal L, Betanzos A, Nava P \& Jaramillo BE (2003) Tight junction proteins. Prog Biophys Mol Biol 81, 1-44.

13. Karczewski J \& Groot J (2000) Molecular physiology and pathophysiology of tight junctions III. Tight junction regulation by intracellular messengers: differences in response within and between epithelia. Am J Physiol Gastrointest Liver Physiol 279, G660-G665.

14. Lindmark T, Kimura $\mathrm{Y}$ \& Artursson P (1998) Absorption enhancement through intracellular regulation of tight junction permeability by medium chain fatty acids in Caco- 2 cells. J Pharmacol Exp Ther 284, 362-369.

15. Mineo H, Hara H, Shigematsu N, Okuhara Y \& Tomita F (2002) Melibiose, difructose anhydride III and difructose anhydride IV 
enhance net calcium absorption in rat small and large intestinal epithelium by increasing the passage of tight junctions in vitro. J Nutr 132, 3394-3399.

16. Suzuki T \& Hara H (2006) Difructose anhydride III and sodium caprate activate paracellular transport via different intracellular events in Caco-2 cells. Life Sci 79, 401-410.

17. Mariadason JM, Barkla DH \& Gibson PR (1997) Effect of short-chain fatty acids on paracellular permeability in Caco-2 intestinal epithelium model. Am J Physiol 272, G705-G712.

18. Guzman-Aranguez A, Olmo N, Turnay J, Lecona E, PerezRamos P, Lopez de Silanes I \& Lizarbe MA (2005) Differentiation of human colon adenocarcinoma cells alters the expression and intracellular localization of annexins A1, A2, and A5. J Cell Biochem 94, 178-193.

19. Yamane M \& Yamane S (2007) The induction of colonocyte differentiation in CaCo-2 cells by sodium butyrate causes an increase in glucosylceramide synthesis in order to avoid apoptosis based on ceramide. Arch Biochem Biophys 459, 159-168.

20. Mineo H, Amano M, Minaminida K, Chiji H, Shigematsu N, Tomita F \& Hara H (2006) Two-week feeding of difructose anhydride III enhances calcium absorptive activity with epithelial cell proliferation in isolated rat cecal mucosa. Nutrition 22, 312-320.

21. Hara H, Suzuki T, Kasai T, Aoyama Y \& Ohta A (1999) Ingestion of guar gum hydrolysate, a soluble fiber, increases calcium absorption in totally gastrectomized rats. J Nutr 129, 39-45.

22. Asvarujanon P, Ishizuka $S \&$ Hara H (2005) Promotive effects of non-digestible disaccharides on rat mineral absorption depend on the type of saccharide. Nutrition 21, 1025-1035.

23. Minamida K, Asakawa C, Sujaya IN, Kaneko M, Abe A, Sone T, Hara H, Asano K \& Tomita F (2006) Effects of long-term ingestion of difructose anhydride III (DFA III) on intestinal bacteria and bile acid metabolism in humans. J Biosci Bioeng 101 149-156.

24. Hadjiagapiou C, Schmidt L, Dudeja PK, Layden TJ \& Ramaswamy K (2000) Mechanism(s) of butyrate transport in Caco-2 cells: role of monocarboxylate transporter 1. Am J Physiol Gastrointest Liver Physiol 279, G775-G780.

25. Schroder O, Opritz J \& Stein J (2000) Substrate and inhibitor specificity of butyrate uptake in apical membrane vesicles of the rat distal colon. Digestion 62, 152-158.

26. Suzuki T \& Hara H (2004) Ingestion of guar gum hydrolysate, a soluble and fermentable nondigestible saccharide, improves glucose intolerance and prevents hypertriglyceridemia in rats fed fructose. J Nutr 134, 1942-1947.

27. Duncan DB (1955) Multiple range and multiple F test. Biometrics 11, 1-42.

28. Laukoetter MG, Bruewer M \& Nusrat A (2006) Regulation of the intestinal epithelial barrier by the apical junctional complex. Curr Opin Gastroenterol 22, 85-89.
29. Turner JR (2006) Molecular basis of epithelial barrier regulation: from basic mechanisms to clinical application. Am J Pathol 169, 1901-1909.

30. Mitsui R, Ono S, Karaki S \& Kuwahara A (2005) Neural and non-neural mediation of propionate-induced contractile responses in the rat distal colon. Neurogastroenterol Motil 17, 585-594.

31. Mariadason JM, Kilias D, Catto-Smith A \& Gibson PR (1999) Effect of butyrate on paracellular permeability in rat distal colonic mucosa ex vivo. J Gastroenterol Hepatol 14, 873-879.

32. Lambo-Fodje AM, Oste R \& Nyman ME (2006) Short-chain fatty acid formation in the hindgut of rats fed native and fermented oat fibre concentrates. Br J Nutr 96, 47-55.

33. Charney AN, Micic L \& Egnor RW (1998) Nonionic diffusion of short-chain fatty acids across rat colon. Am J Physiol 274, G518-G524.

34. Klonk S \& Deuticke B (1992) Involvement of cytoskeletal proteins in the barrier function of the human erythrocyte membrane. III. Permeability of spectrin-depleted inside-out membrane vesicles to hydrophilic nonelectrolytes. Formation of leaks by chemical or enzymatic modification of membrane proteins. Biochim Biophys Acta 1106, 143-150.

35. Brown AJ, Goldsworthy SM, Barnes AA, et al. (2003) The orphan G protein-coupled receptors GPR41 and GPR43 are activated by propionate and other short chain carboxylic acids. J Biol Chem 278, 11312-11319.

36. Karaki SI, Tazoe H, Hayashi H, Kashiwabara H, Tooyama K, Suzuki Y \& Kuwahara A (2007) Expression of the short-chain fatty acid receptor, GPR43, in the human colon J Mol Histol (Epublication ahead of print version).

37. Karaki S, Mitsui R, Hayashi H, Kato I, Sugiya H, Iwanaga T, Furness JB \& Kuwahara A (2006) Short-chain fatty acid receptor, GPR43, is expressed by enteroendocrine cells and mucosal mast cells in rat intestine. Cell Tissue Res 324, 353-360.

38. Kong KC, Billington CK, Gandhi U, Panettieri RA Jr \& Penn RB (2006) Cooperative mitogenic signaling by $G$ proteincoupled receptors and growth factors is dependent on $\mathrm{G}(\mathrm{q} / 11)$. FASEB $J$ 20, 1558-1560.

39. Simons K \& Ikonen E (1997) Functional rafts in cell membranes. Nature 387, 569-572.

40. Brown DA \& London E (2000) Structure and function of sphingolipids-and cholesterol-rich membrane rafts. J Biol Chem 275, $17221-17224$.

41. Muller G (2002) Dynamics of plasma membrane microdomains and cross-talk to the insulin signalling cascade. FEBS Lett 531, $81-87$.

42. Nusrat A, Parkos CA, Verkade P, Foley CS, Liang TW, InnisWhitehouse W, Eastburn KK \& Madara JL (2000) Tight junctions are membrane microdomains. J Cell Sci 113, 1771-1781. 